\title{
The invasion and expansion of three North American species of goldenrod (Solidago canadensis L. sensu lato, S. gigantea Ait. and S. graminifolia (L ) Salisb ) in Poland
}

\author{
MALGORZATA GUZIKOWA ' PAUL F. MAYCOCK ${ }^{2}$
}

${ }^{1}$ Institute of Botany. Polish Academy of Sciences. Lubicz 46. 31-512 Kraków. Poland

2 Department of Botany. University of Toronto. Erindale College. Mississauga. Ontario. Canada. L5L 1C6

(Received: February 2 1986. Accepted April 11 1986)

ABSTRACT

The geographical distributions of three adventive species of North American goldenrods (S. canadensis L. s.1., S. gigantea Ait. and S. graminifolia (L.) Salisb.) throughout Poland are presented. The history of escape, initial establishent and subsequent spread are documented on the basis of almost 1400 herbarium collections and site records of the authors. Of the three species. $S$. gigantea is the most aggressive $S$. canadensis has continued to spread vigorously. but $S$. graminifolia has barely moved beyond its initial area of establishment. The first two species occur essentially throughout Poland. having expanded from centers in southwestern Poland in the decade between 1840 to 1850 . Both of these plants are spreading rapidly and producing vigorous populations which thrive in disturbed and semi-disturbed environments and $S$. gigantea seems to have now attained the capability of invading stabilized habitats and communities. They are in the process of becoming a serious threat to many natural environments and ecosystems in Poland.

Key words: Solidago, introduced, invasion, expasion, distribution, habitats

\section{INTRODUCTION}

Four representatives of the genus Solidago L. (goldenrods) occur naturally in Poland. Only a single species is native in Europe - Solidago virga-aurea L.. and the other three - S. canadensis L. s.1.. S. gigantea Ait. and S. graminifolia (L.) Salisb., are of alien origin.

It is generally understood that the aliens were introduced into Europe from original areas of distribution in eastern North America, during the first half of the XIX century as desirable horticultural plants and as nectar sources for honey production. S. canadensis and $S$. gigantea are still 
highly valued as ornamentals and as food for honey bees. The golden inflorescences produce abundant nectar and masses of pollen and late in the season (blooming predominantly in August and September when most of the native European sources have already flowered), and the plants are thus encouraged in gardens, parks cemeteries, etc.

For a considerable period they have managed to escape from cultivation and have become abundant in various ruderal habitats, such as fencerows. roadsides, dump sites, etc. Establishment in these environments has been spontaneous due to abundant tiny, light, wind-dispersed seed or due to vegetative proliferation from fragments discarded in garden debris. More recently it is apparent that some of these species have succeeded in establishing in more stable habitats and may be becoming a threat to natural communities, particularly those where natural soil disturbance regularly occurs - meadows, thickets, river and streambank communities. etc.

It is noteworthy that $S$. canadensis and $S$. gigantea have displayed an unusual ability to expand their distributions not only throughout Polish territory but throughout central Europe and evidently so during the last few decades. To the contrary, S. graminifolia does not show any evidence of aggressive expansion.

The purpose of this contribution is first to clarify the present distributions of the three adventive North American species in Poland, and secondarily an attempt is made to reconstruct the history of the spread of these species through the country, with special regard to southern Poland. The attainment of significantly high population levels of the two aggressive members emphasizes the need to not only be knowledgeable about existing distributions, but to gain an understanding of their life history characteristics.

\section{MATERIAL AND METHODS}

On first recognizing the many problems associated with field identification and species determinations in Polish herbaria, the analysis has been based exclusively on specimens which have been either revised or in the case of $S$. canadensis and $S$. gigantea, based on specific field investigations of the authors. The authors drove many of the highways in the southern part of Poland as well as major north-south arteries in central Poland during the summer and autumn of 1982, and added considerably to the repository of specimens and to the data base on species occurrences.

In preparing distributional maps for the species in Poland, herbarium specimens were obtained on loan from the following institutions and private sources:

- Instytut Badawczy Leśnictwa, Białowieża;

- Instytut Biologii UG, Gdynia; 
- Instytut Biologii WSP, Kielce;

- Instytut Botaniki UJ, Kraków (KRA);

- Instytut Botaniki PAN, Kraków (KRAM);

- Instytut Biologii UMCS, Lublin (LUB) ${ }^{3}$;

- Instytut Biologii Środowiskowej UŁ, Łódź (LOD);

- Akademia Rolniczo-Techniczna, Olsztyn (OLSZ);

- Instytut Biologii UAM. Poznań (POZ);

- Zakład Biologii WSP. Słupsk;

- Zakład Taksonomii, Ekologii Roślin i Ochrony Przyrody UMK, Toruń (TRN);

- Instytut Botaniki UW. Warszawa (WA);

- Private herbarium of Prof. Dr. Józef Mądalski. Wrocław;

- Private specimens (Zakopane region) of Drs. Halina and Zbigniew Mirek. Kraków.

Table 1

Statistics of collections of the three Solidago spp. used in the analysis

\begin{tabular}{|c|c|c|c|}
\hline & S. canadensis s.l. & S. gigantea & S. graminifolia \\
\hline $\begin{array}{l}\text { Total herbarium specimens } \\
\text { examined }\end{array}$ & 316 & 519 & 26 \\
\hline $\begin{array}{l}\text { Number of sight records and } \\
\text { collections of the authors'. }\end{array}$ & & & \\
\hline $\begin{array}{l}\text { Mostly in southern Poland } \\
\text { Total localities mapped in }\end{array}$ & 170 & 350 & 0 \\
\hline Poland & 290 & 476 & 11 \\
\hline $\begin{array}{l}\text { Total localities mapped in } \\
\text { southern Poland }\end{array}$ & 162 & 272 & 11 \\
\hline $\begin{array}{l}\text { Total sites including collections } \\
\text { and/or site records }\end{array}$ & 494 & 866 & 26 \\
\hline $\begin{array}{l}\text { Total sites including habitat } \\
\text { information - Poland }\end{array}$ & 545 & 621 & 21 \\
\hline -S. Poland & 250 & 462 & 20 \\
\hline Unidentifiable localities omitted & 10 & 19 & 0 \\
\hline
\end{tabular}

A total of 861 herbarium records have been revised (316 S. canadensis, 519 S. gigantea and 26 S. graminifolia). Statisctical details of these revisions are shown in Table 1.

\section{RESULTS}

RATE OF INCREASE IN THE HERBARIUM COLLECTIONS OF GOLDENRODS IN POLAND

Based on the accumulated data, the rate of increase of locality occurrences for each of the three goldenrod species in 10 year period intervals,

${ }^{3}$ Except Solidago graminifolia specimens. 
has been analyzed (Fig. 1). The curve for S. graminifolia indicates a low level and yet a slow and uniform increase in the number of localities throughout a century of collecting between 1885 and 1985. To the contrary, the other two species pertray two or even three phases in respect to the

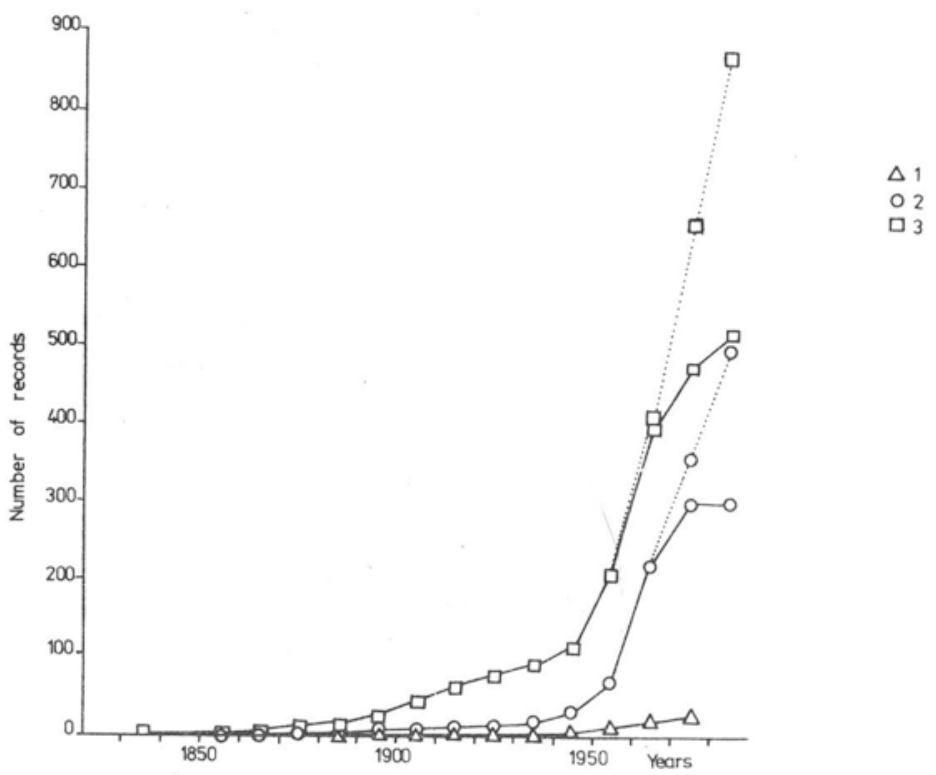

Fig. 1. Stations for Solidago graminifolia (1), S. canadensis s.l. (2) and S. gigantea (3) in Poland. presented by decades. Based on herbarium collections (solid lines); total observations including collections and sight records (dotted lines)

rate of increase of collections representing different localities of occurrence. The initial represents first collections in natural or wild situations, from 1836 to 1890 for S. gigantea and between 1853 to 1900 for S. canadensis. Then there is a phase representing a slow increase in the number of localities occurring between 1890 and 1950 and 1900 and 1950 respectively, for these species. Finally for both there is a third phase involving a rapid increase in the number of localities after 1950. The last aspect which has been clearly evident recently, undoubtedly is a reflection on the progress of floristic research following the second world war, but also an explosion in the invasion of these aggressive plant species.

DISTRIBUTION IN POLAND

Present pattern of distribution in relation to areas occupied throughout Europe

In Flora Europaea (1976), S. canadensis and $S$. gigantea are shown to be represented in most countries, whereas $S$. graminifolia seems restricted 


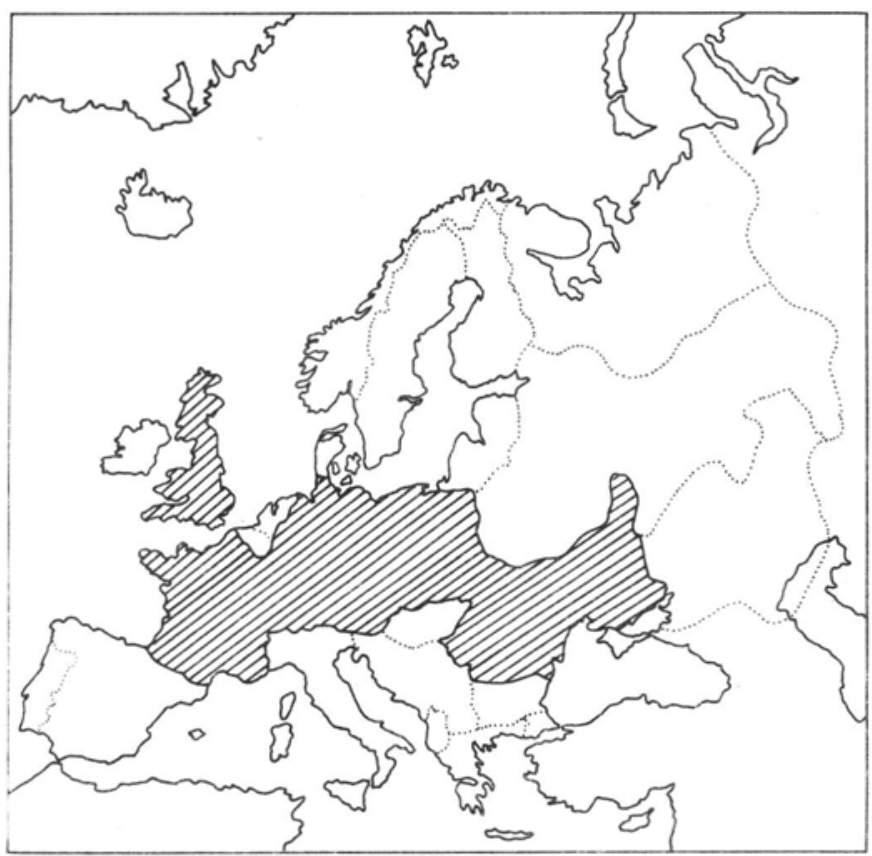

Fig. 2. Geographical distribution of Solidago graminifolia in Europe as presented in Flora Europaea (1976)

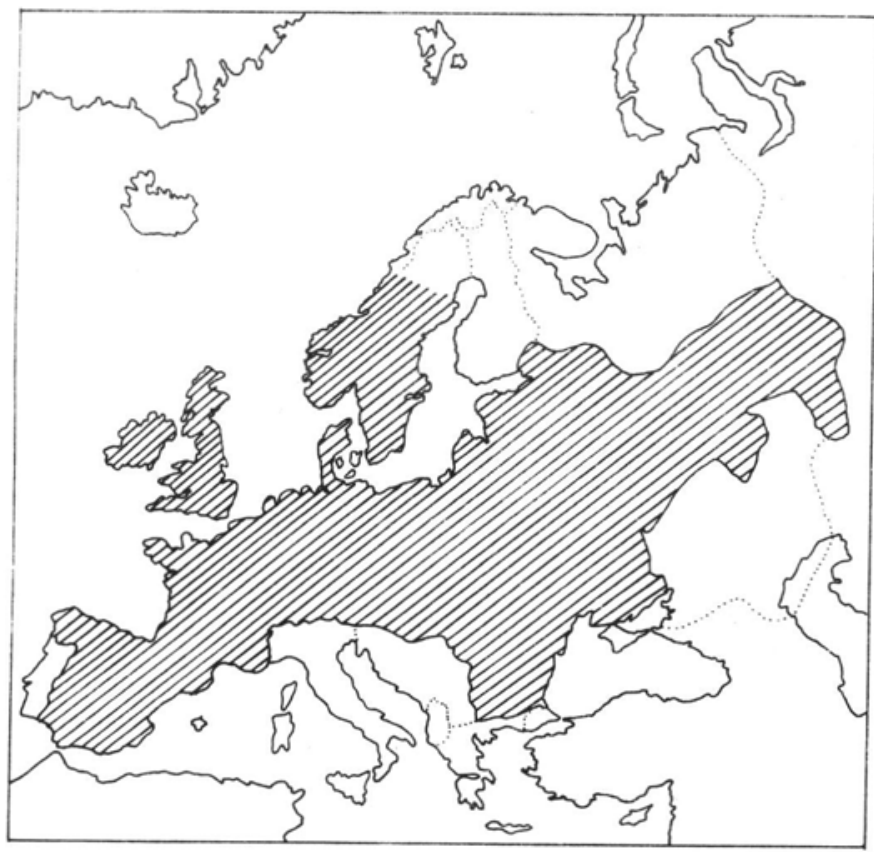

Fig. 3. Distribution of Solidago canadensis s.l. in Europe as presented in Flora Europaea (1976) and by Nilsson (1976) 
372

M. Guzikowa, P. F. Maycock

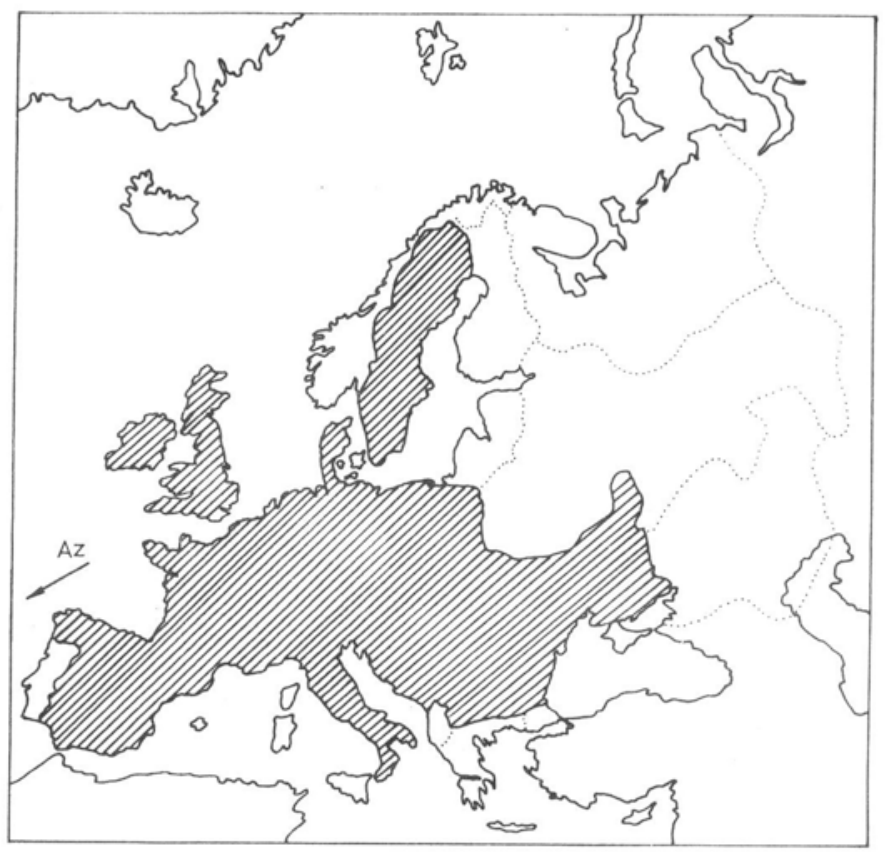

Fig. 4. Distribution of Solidago gigantea in Europe as presented in Flora Europaea (1976)

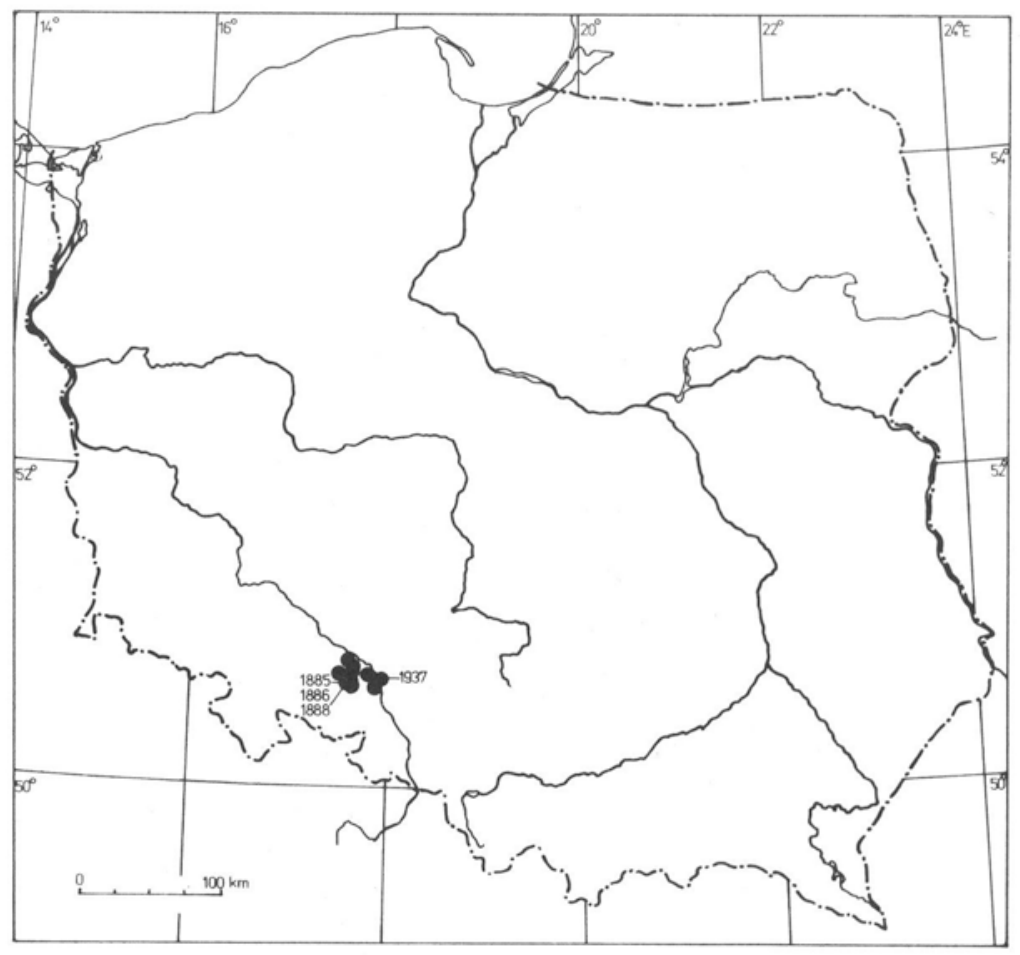




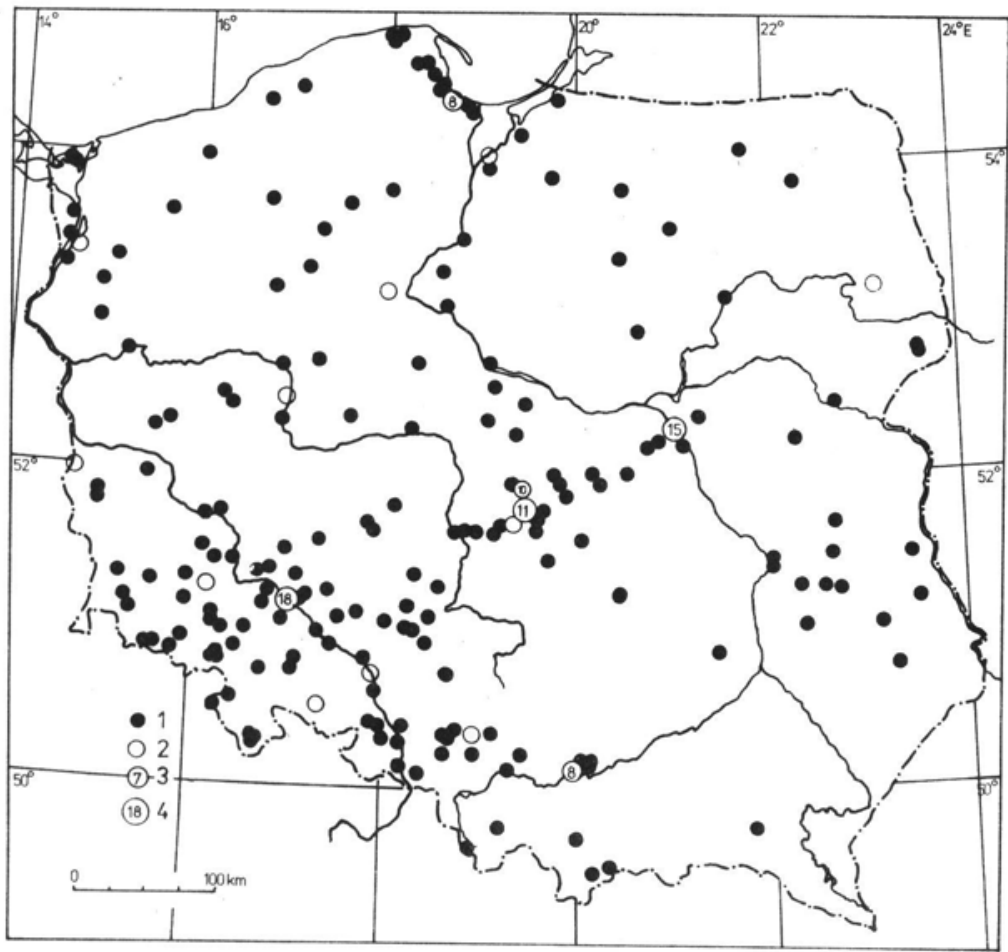

Fig. 6. Distribution of Solidago canadensis s.l. in Poland based on original herbarium records. 1 -localities represented by $1-2,2$ - by $3-5,3$ - by $6-10$ as indicated by the value, 4 - by $11-20.5$ - by $20+$, collections

to central regions (Figs. 2-4). The first two appear as widely distributed species while the last one occurs in the wild only sporadically.

Similarly, maps of the distribution of these species in Poland, show significant differences not only in respect to frequency of occurrence, but also in regard to the character and dynamics of their secondary distributions. These differences have largely resulted from the different biological features of the respective species.

Having grown in the wild in Poland for longer than a century and a half, $S$. canadensis and $S$. gigantea have succeeded in extending their distributions throughout the entire country. On the other hand, the natural range of $S$. graminifolia, for the period of a century which has elapsed 
since its first discovery as an escape, has been extended only slightly and it continues to remain restricted to the same limited area where it was originally collected - in the vicinity of Niemodlin and Opole in Lower Silesia. The localities listed by K. Rostański in Flora Polska (1971): Chojnów, and according to Abromeit (1898), Murgiszki at Gołdap (this latter locality is situated in the Mazovian Lake District (Pojezierze Mazurskie), but in actual fact somewhat beyond the boundary of Poland

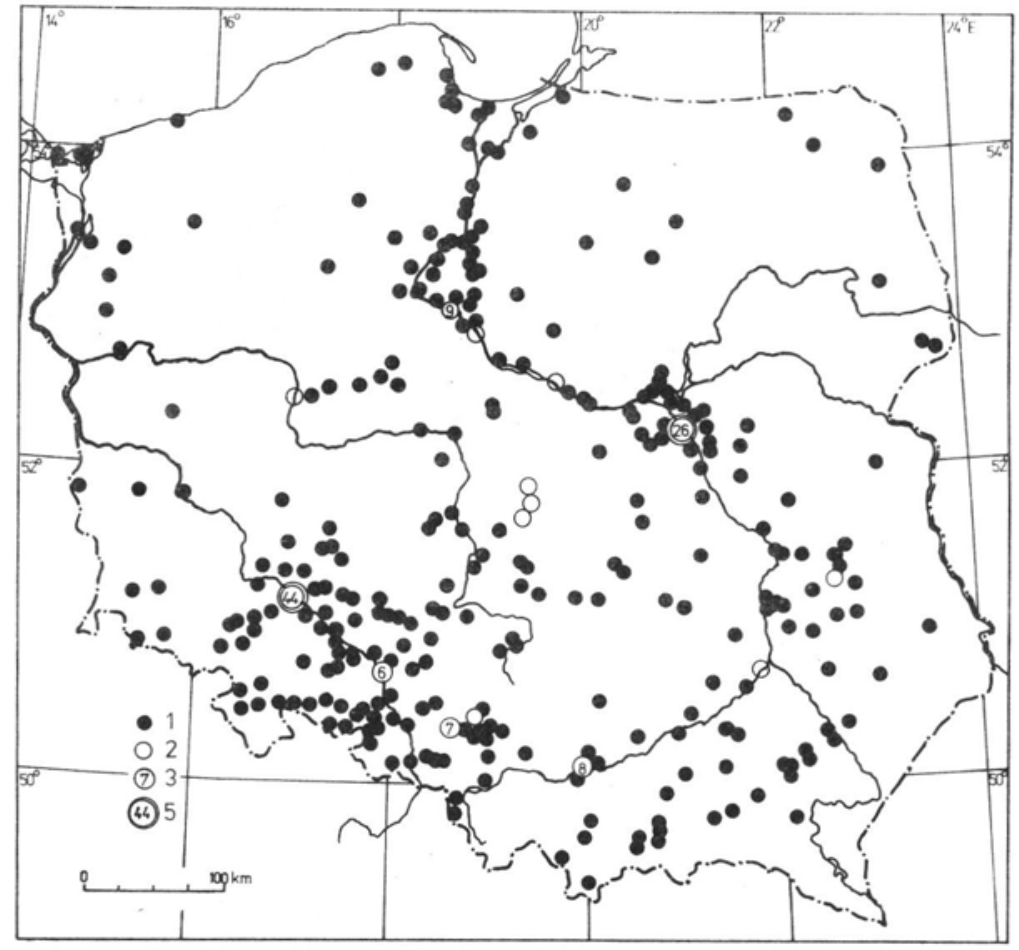

Fig. 7. Distribution of Solidago gigantea in Poland based on original herbarium records. Symbols as in Fig. 6

in Lithuania SSR), are not verified by herbarium records. On the distributional map of this species in Poland (Fig. 5) the dates of the earliest collections to 1939 have been specified and the other localities are records for the period after 1960 .

A comparison of figures 6 and 7 does not fully support the contention published in Flora Polska (1971), that S. canadensis is "considerably rarer" in Poland than $S$. gigantea although it is undoubtedly less common in many regions of the country. The difference is resolved not only by a fewer number of localities of occurrence but also by their different distribution and frequency.

In the case of $S$. canadensis, a significant concentration of occurrences 
is noted in the southwestern and central areas of the country; in north and northeastern Poland there are fewer occurrences and an apparent gap is observed in the southeastern sector. S. gigantea is common in central and southern Poland and is concentrated along the entire length of the Vistula River valley.

On the basis of both distribution maps (Figs. 6 and 7) it is difficult to decide whether the low occurrences of these species in the Pomeranian, Mazovian and western Greater Poland lake districts (Pojezierze Pomorskie, Pojezierze Mazurskie, Pojezierze Wielkopolskie) and also in the Podlasie Lowland (Nizina Podlaska), are commensurate with the actual situation or whether this has resulted from scanty exploration of these regions.

An attempt to reconstruct the history of the invasion and spread of the goldenrod species in Poland

Some assistance in interpreting the current patterns of occurrence of $S$. canadensis and $S$. gigantea might be provided by viewing the distributions

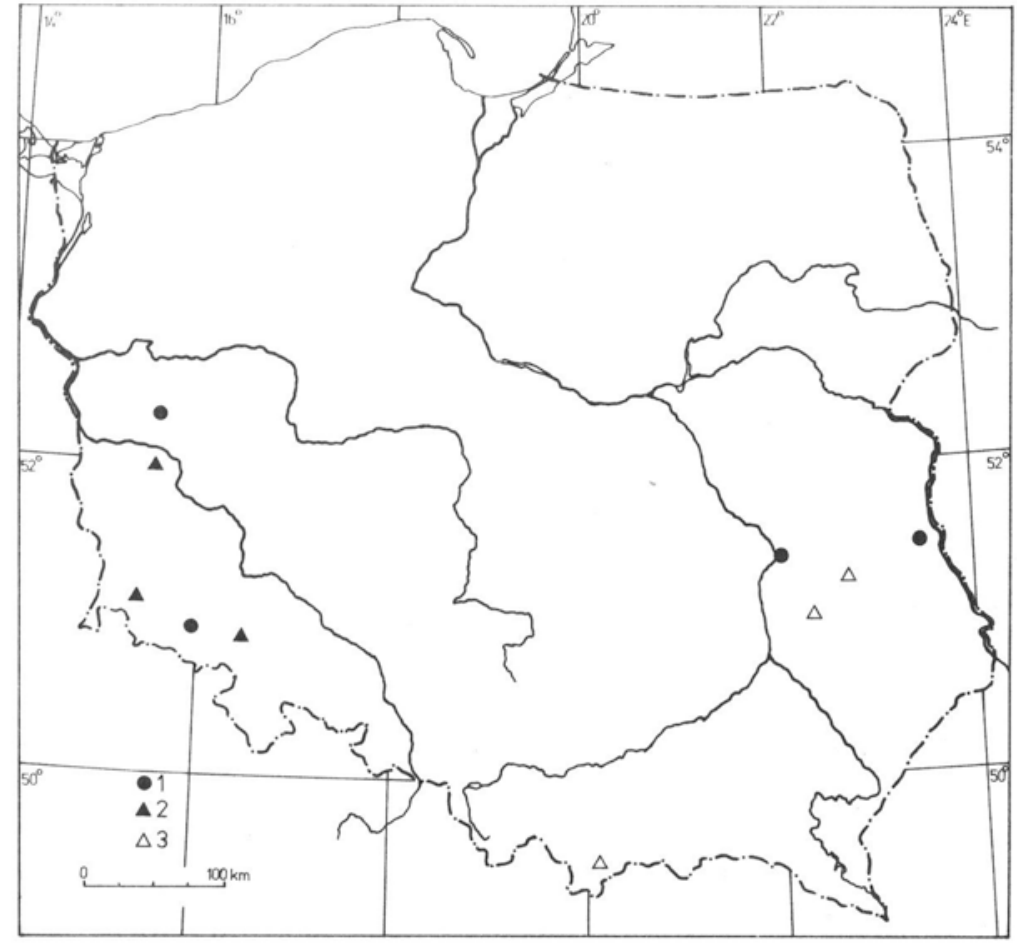

Fig. 8. Distribution of the oldest site locations for Solidago canadensis s.l. in Poland, based on herbarium records: 1 - before 1900, 2 - 1901-1914, 3 - 1915-1939 
of their earliest adventive localities, as judged from herbarium records obtained prior to the second world war (Fig. 8 and 9). Specimens collected up to 1900, between 1901 and 1914 and from 1915-1939, are differentiated.

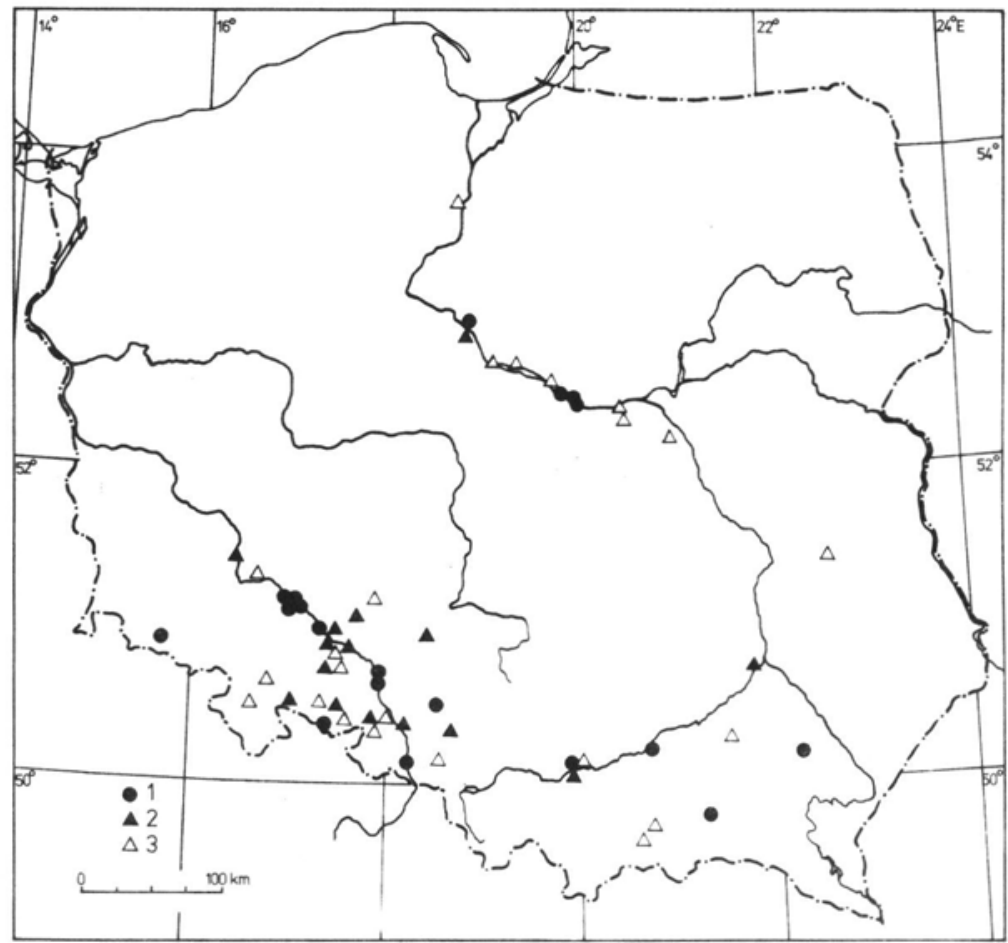

Fig. 9. Distribution of the oldest site locations for Solidago gigantea in Poland based on herbarium specimens. Symbols as in Fig. 8

The most striking aspect of the early establishment sites of $S$. gigantea is their proximity to river systems. This is true for the two initial periods and only in the 1915-1939 interval do collections turn up in sites removed from the rivers. It is also clearly evident that even in the period up to 1900, it was then common in the Silesian Lowlands (Nizina Śląska) and in the Sudeten Mountains, as well as in many places along the Vistula River below Warsaw. As well, although not as common, it was also found in the Sandomierz Basin (Kotlina Sandomierska). Evidence from herbarium labels indicates that even in the 1860 's, $S$. gigantea was well established in semi-natural and natural habitats and was collected not only in ruderal situations but also in riverbank willow thickets, specifically along the Olza River in the vicinity of Racibórz (legit Ascherson, 1866 WRSL $^{4}$ and along the Ropa River about Biecz (legit Kotowicz, 1870, KRAM).

${ }^{4}$ Explanation of herbaria abbreviations. see in Materials and Methods. 
The analagous distribution map for $S$. canadensis stands in marked contrast. It is poor in early collections and almost all of these are associated with sites well separated from river valleys. There are only a few herbarium collections, prior to 1900, and these refer almost exclusively to ruderal habitats and some may be cultivars. Many of the labels show a lack of habitat information ${ }^{5}$.

There are barely a dozen localities represented in the collections prior to 1939 and in none of these does $S$. canadensis occur in anything but disturbed or cultivated situations. The unusual aspect of these records is that they occur in regions widely separated in the southwestern, and southeastern extremities of Poland specifically in the southwestern Greater Poland Lowland and in the Sudeten Mountains and in the southeastern Lublin Upland. It is probable that expansion from these two centers has subsequently extended the range of this species throughout the remaining areas of the country.

Details of the distributions of $S$. canadensis s.l. and $S$. gigantea in southern Poland

An intensive examination of the specific occurences of goldenrod populations in the field permit a more penetrating analysis of $S$. canadensis

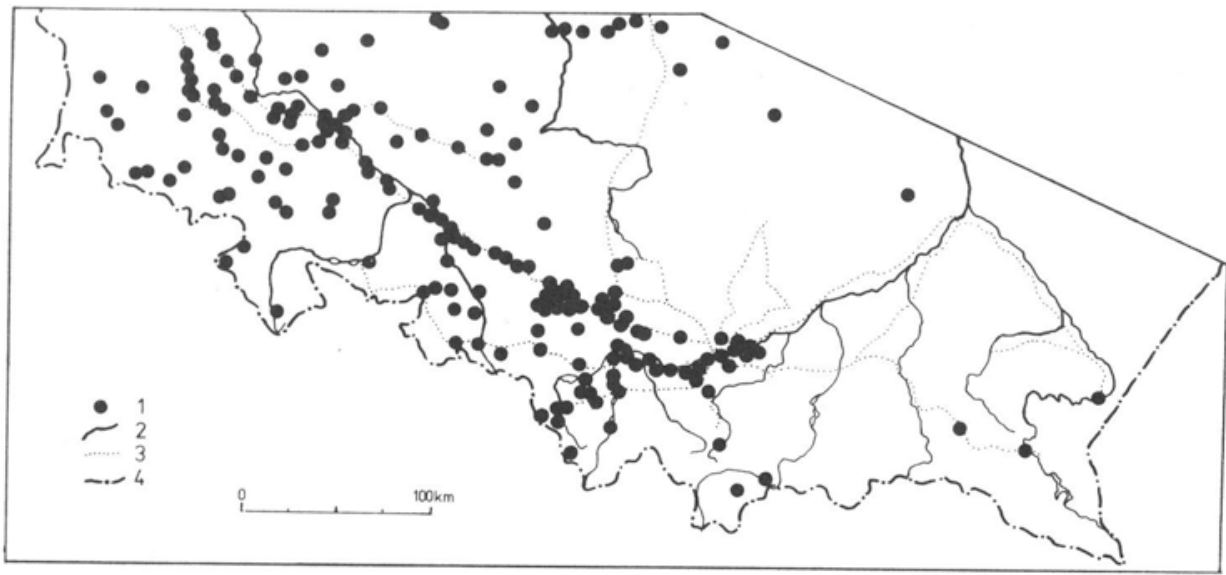

Fig. 10. Distribution of Solidago canadensis s.l. in southern Poland on the basis of herbarium records and sight records of the authors. 1-locations, 2-rivers, 3-routes travelled by car searching for Solidago occurences, 4 - boundaries of Poland

5 In the light of these facts, information provided by Fiek (1881) seems to be entirely credible. He noted that $S$. gigantea (as $S$. serotina Ait.) grew in the wild state, "especially in the Odra River valley", where it then was represented by, "permanent locations", as opposed to $S$. canadensis, which was mentioned only on the basis of sporadic observations. 
and $S$. gigantea presence in southern Poland. Figures 10 and 11 portray an updated picture of the distribution of both species which has been revised on the basis of extensive data obtained during highway excersions in 1982.

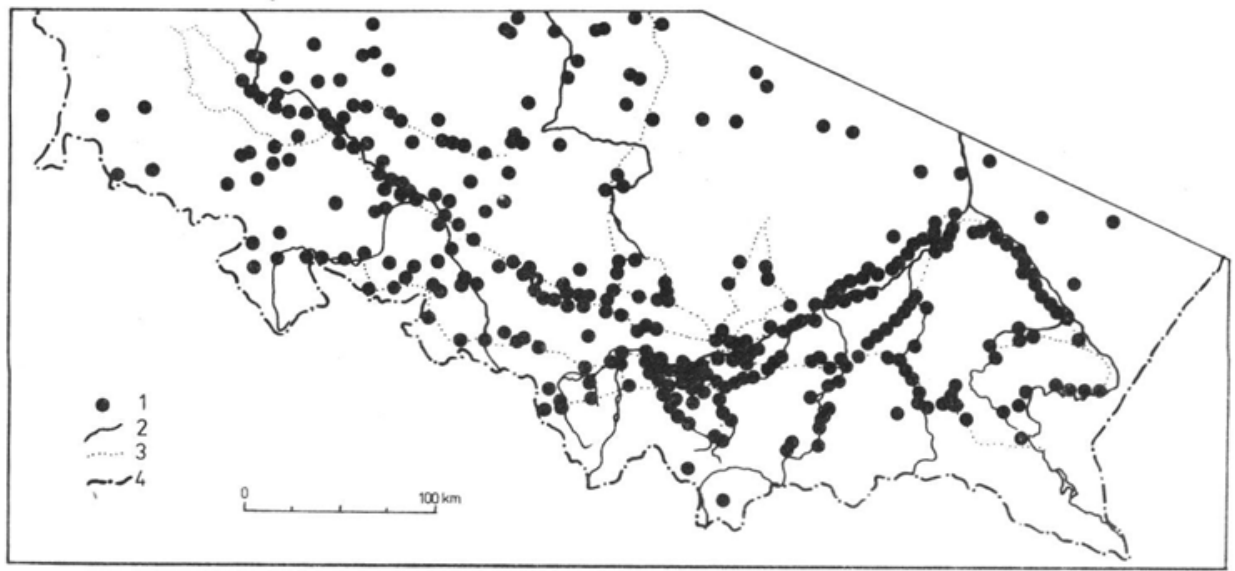

Fig. 11. Distribution of Solidago gigantea in southern Poland based on herbarium records and sight records of the authors. Symbols as in Fig. 10

S. gigantea is widely distributed throughout southern Poland. It is perhaps only less frequent in the Sudeten Mountains region and in the central areas of the Lesser Poland Upland (Wyżyna Środkowo-Małopolska). A great majority of the locations where the species occurs bear a significant relation to the river valleys, as well as with the road and railway communication systems.

The localities for $S$. canadensis in southern Poland which are found from the extreme eastern limits of Cracow westward, assume a remarkably similar pattern to that of $S$. gigantea, but without a strong connection to river valleys. East of Cracow however, only rare, single and very dispersed localities of this species are observed.

\section{Habitat analysis}

An analysis of the habitat types where herbarium specimens of the three introduced goldenrod species have been collected, has been performed with reference to the physico-geographical divisions of Poland to Kondracki (1978) and are presented in Fig. 12.

Herbarium specimen information indicates that $S$. graminifolia grows most often in ditches, on the fringes of ponds and clay pits and in various other moist and wet places, but such sites as dry sunny hills, dry roadsides and forest edges, are also noted. $S$. gigantea is also found 


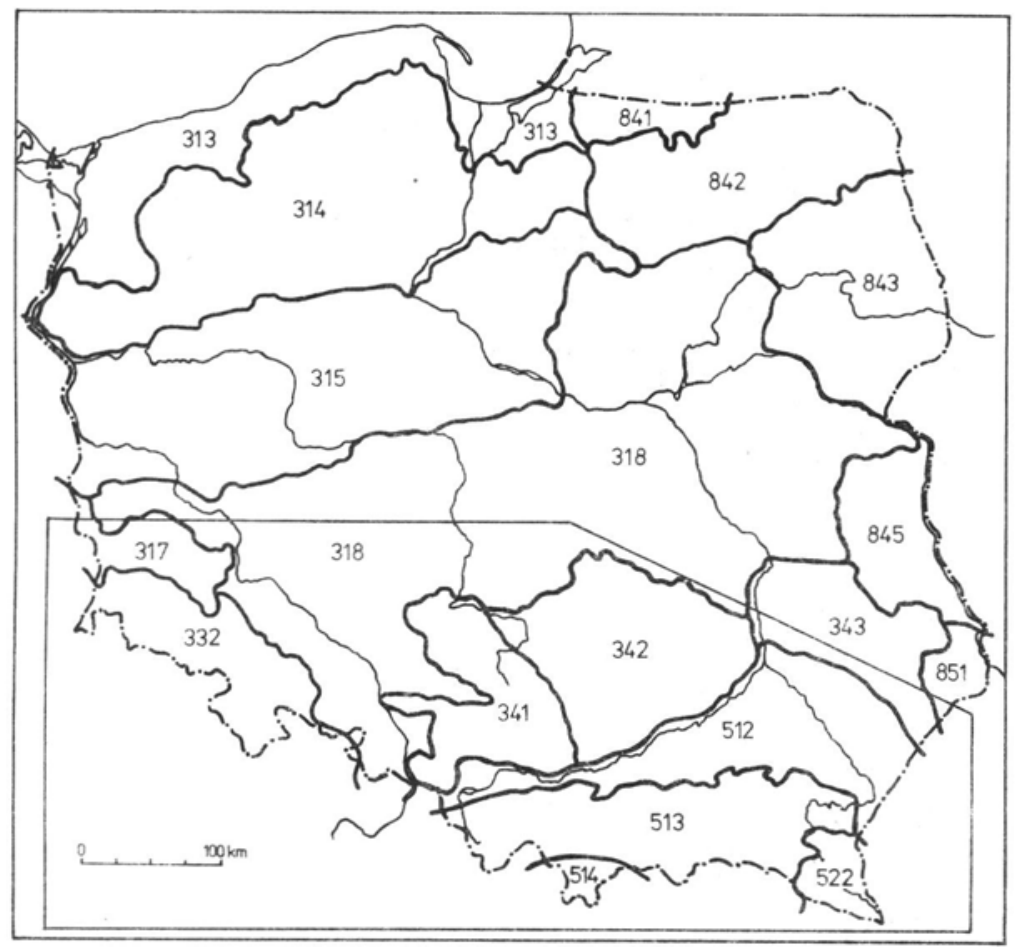

Fig. 12. Map presenting the more important physico-geographical divisions of Poland (Kondracki 1978): 313 - South Baltic Sea Coast (Pobrzeża Poludniowo Bałtyckie), 314/315 South Baltic Lake District (Poiezierza Południowo-Bałtyckie), 317 - Saxony-Lusatian Lowlands (Niziny Sasko-Łużyckie), 318 - Central Polish Lowland (Niziny Środkowopolskie), 332 Sudeten Mountains (Sudety), 341 - Silesian-Cracowian Upland (Wyżyna Śląsko-Krakowska), 342 - Central Lesser Polish Upland (Wyżyna Środkowomałopolska), 343 - Eastern Lesser Polish Upland (Wyżyna Środkowomałopolska), 343 - Eastern Lesser Polish Upland (Wyżyna Wschodniomałopolska), 512 - Northern Carpathian Piedmont (Północne Podkarpacie), 513 West Carpathian Outliers (Zewnętrzne Karpaty Zachodnie), 514 - Central Western Carpathians (Centralne Karpaty Zachodnie), 522 - Eastern Beskids (Beskidy Wschodnie), 841 - Eastern Baltic Sea Coast (Pobrzeża Wschodniobałtyckie), 842 - Eastern Baltic Lake District (Pojezierza Wschodniobałtyckie). 843 - Podlasian White Russian Highlands (Wysoczyzny Podlasko-Białoruskie), 845 - Polesia (Polesie), 851 - Wołyń-Podolian Upland (Wyżyna Wołyńsko-Podlaska). Those regions of southern Poland in which a search for $S$. canadensis s.l. and $S$. gigantea occurrences were carried out are blocked

in rather moist environments, although this species is characterized by a particularly broad range of tolerance for soil moisture. Most of the records for $S$. canadensis indicate moderately dry upland conditions.

The percentage of localities of occurrence of each goldenrod species for each of seven differentiated groups of habitats (Fig. 13) within a particular physico-geographical unit (Fig. 12) is shown in Figs 13 and 14. 
All the localities of $S$. graminifolia in Poland have been situated within one physico-geographical region (Fig. 13). The analogous percentage of localities of occurrences for $S$. canadensis and $S$. gigantea in the particular physico-geographical regions of southern Poland have been ordered from

Solidago graminifolia

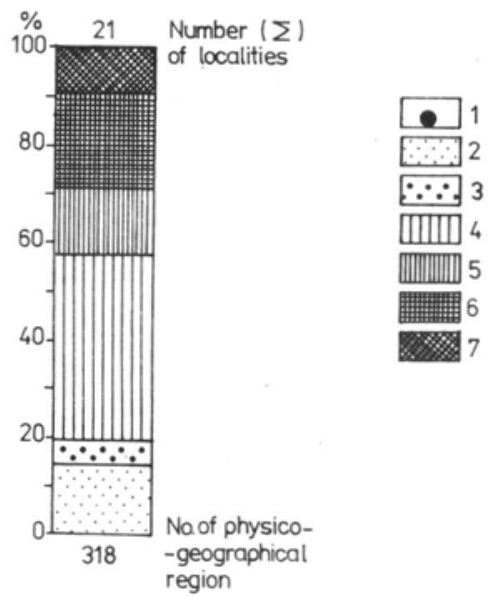

Fig. 13. The percentage occurrence of Solidago graminifolia in seven habitat groupings within the specific physico-geographical region of Poland (for explanation see Fig. 12). 1 - Cultivated: gardens. cemeteries. parks. etc.; 2 - strict ruderal sites-adiacent to houses. fencerows. roadsides, railway yards, dump sites, rubble heaps, town squares, repositories; 3 - old fields. fallow, grassy barrens, field edges; 4-meadows, balks. pastures. ditches; 5-thickets and groves (not in river valleys) generally exposed and disturbed on the fringes, plantations-poplar, self-seeded pine, glades, clearings; 6 - semi-natural habitats along watercourses. riverbanks, streams, canals, lakes and ponds, alluvial deposits, valley slopes, willow carrs. remnants of bottomland forests (willow, poplar or alder), dams, etc.; 7 - other habitats of a semi-natural character (disturbed maritime dunes and depressions, loess and chalk slopes, quarries, dry slopes, etc.)

west to east or more specifically from west northwest to east southeast (Fig. 14). Despite the fact that both species have been collected in very different types of habitat, it is evident that $S$. canadensis is much more closely associated with typically ruderal situations than with semi-natural ones. With $S$. gigantea however, there is a tendency toward semi-natural habitats, mostly those associated with the fringes of water and especially riversides. Many field observations confirm that this preference is evident not only in terms of the number of locations but also in an incomparably greater abundance of $S$. gigantea in semi-natural habitats in comparison with $S$. canadensis. 

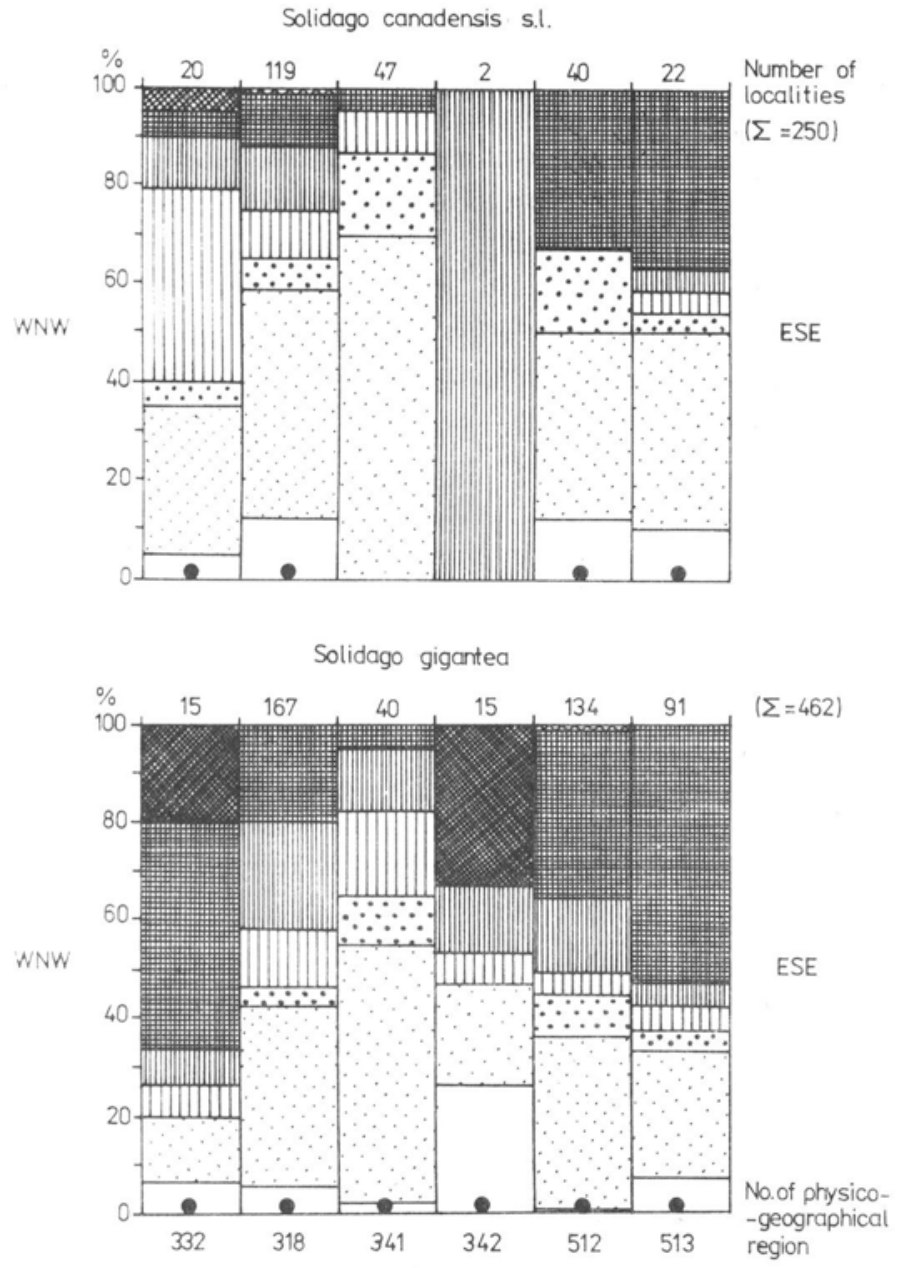

Fig. 14. The percentage occurrence of Solidago canadensis s.l. and S. gigantea in the seven habitat groupings within the specific physico-geographical regions of Poland, ordered along a transect from west-northwest to east-southeast. For explanations see Figs. 12 and 13

\section{DISCUSSION AND CONCLUSIONS}

In analyzing the distribution maps of these goldenrod species, one is reminded that some aspects of the irregular distribution patterns of $S$. canadensis and $S$. gigantea in Poland may be the result, to a degree. of varying intensity of observation and collecting in different regions of the country. It reveals among other things, a localization of collecting in the vicinity of university centers, as for example near Łódź, Lublin. Gdańsk. etc. 
As well, not all distributional gaps necessarily correspond with real absences of the species.

Similarly an analysis of the oldest location records throughout Poland indicates that complete information is not available and it is not possible to estimate what fraction of herbarium collections of the past century has been preserved to the present period.

On the other hand, however, it seems that despite these possible restrictions, the results which have been presented are sufficient to permit the formulation of the following conclusions:

1. Two of these three adventive species of North American Solidago must be included among the most aggressive introductions to Poland.

2. S. canadensis s.l. and S. gigantea have become widespread in their distribution throughout Polish territory and continue to portray uncontrollable expansion. S. gigantea is found on a national scale, more frequently and more numerous than $S$. canadensis, although in certain regions notably the Lake District and Podlasie Lowland, the spread of this species has not yet attained an expansive nature. S. canadensis displays fairly significant differences in the frequency of occurrence and local abundance as well as the degree of acclimatization and naturalization. It is uncommon in north and northeastern Poland, is common in Lower and Upper Silesia in the southwest, and has not yet been discovered out of cultivation in southeastern Poland.

Contrary to the situation presented for both of the above species, the area of distribution of $S$. graminifolia is limited to a single geographical locality in Lower Silesia which has expanded ever so slightly during the past century of its naturalization. The number of known stations for this species is still small.

3. The expansion of $S$. gigantea throughout Polish territory began probably about 20-30 years earlier (circa 1836) than that of S. canadensis and it seems to have spread much more rapidly.

4. In the case of $S$. gigantea, the principal migration routes were evidently river and stream valleys and particularly that of the Vistula in central Poland., Road and railway rights of way however, have played significant roles in the rapid expansion of both species.

5. The occurrence of $S$. graminifolia is principally connected with moist and wet habitats of anthropogenic origin - ditches, pond edges, clay pites, etc. S. gigantea clearly is favoured by moist habitats and owing to an exceptionally broad tolerance for wet situations, can also establish in dry habitats which only are periodically inundated. Conversely, S. canadensis seems to be generally associated with moderately dry environments.

$S$. canadensis is, in Poland, at the majority of the localities of occurrence. associated with strictly ruderal situations, whereas semi-natural environments characterize the predominant segment of the herbarium collections of S. gigantea. 
6. Relative to continued intensified environmental destruction and incessant perturbations in areas already devasted, and to the increasing extension of communications, there is great apprehension that favourable conditions for the rapid expansion of $S$. canadensis and $S$. gigantea in Polland will continue into the future. This thus posses an even greater threat for the possible destruction of natural ecosystems and environments, particularly those of stabilized situations. Both of these species of goldenrod remain in a phase of unabated expansion and it cannot be anticipated that this process will be slowed and certainly never stopped, under prevailing conditions.

\section{Acknowledgments}

The authors express gratitude to the Curators of Herbaria and other workers of the institutions mentioned for making their collections available. Professor Józef Mądalski and Drs. Halina and Zbigniew Mirek allowed the use of unpublished private records and we cannot provide sufficient gratitude to recognize this generosity. We are indebted to Professor Kazimierz Zarzycki and colleagues in the Department of Ecology and Plant Geography. Institute of Botany, Polish Academy of Sciences, Cracow, Poland for their assistance and useful discussions at the time of writing. Thanks to Janusz Guzik who assisted in plotting certain localities during map preparation.

\section{REFERENCES}

Abromeit J., 1898. Flora von Ost- und Westpreussen herausgegeben vom Preussischen Botanischen Verein zu Königsberg i. Pr. Berlin. In Komission bei R. Friedländer u. Sohn.

Fiek E., 1881. Flora von Schlesien preussischen und österreichischen Antheils. J.U. Kern's Verl. (Max Müller), Breslau.

Flora Europaea, 1976. 4. Cambidge Univ. Press.

Flora Polska, 1971. 12. PWN, Warszawa-Kraków.

K ondracki J., 1978. Geografia fizyczna Polski. 3-rd Ed., PWN, Warszawa.

Nilsson A., 1976. Spontana gullrishybrider (Solidago canadensis $\times$ virgaurea) i Sverige och Danmark (Spontaneous Solidago canadensis $\times$ virgaurea in Sweden and Denmark). Svensk Bot. Tidskr. 70: 7-16.

Inwazja i ekspansja trzech pólnocnoamerykańskich gatunków nawloci (Solidago canadensis L. s.l., S. gigantea Ait. i S. graminifolia (L.) Salisb.) w Polsce

\section{Streszczenie}

W pracy omówiono rozmieszczenie geograficzne trzech północno-amerykańskich przedstawicieli rodzaju Solidago L. w Polsce. Na podstawie około 860 arkuszy zielnikowych 7 całego kraju i 520 obserwacji własnych autorów przeprowadzono ponadto próbę odtwo- 
rzenia historii rozprzestrzenienia się tych gatunków oraz analizę typów siedlisk, na jakich były spotykane. Stwierdzono, że $S$. canadensis i $S$. gigantea występują obecnie w całej Polsce i należą do najbardziej ekspansywnych roślin obcego pochodzenia w naszym kraju. $S$. gigantea występuje na ogół częściej i obficiej, niż $S$. canadensis, chociaż w niektórych regionach (m.in. na Pojezierzach, czy Nizinie Podlaskiej) występowanie to nie przybrało jeszcze charakteru masowego. S. canadensis wykazuje znaczne lokalne różnice. zarówno jeśli chodzi o częstość i obfitość występowania, jak też stopień zadomowienia (np. w północno-wschodniej Polsce występuje nielicznie, na Dolnym i Górnym Śląsku-pospolicie, zaś w południowo-wschodniej Polsce nie stwierdzono jej dotąd w stanie zdziczałym). W przeciwieństwie do obu tych gatunków, zasięg $S$. graminifolia obejmuje niewielki. zwarty obszar na Dolnym Śląsku, a liczba jej stanowisk nieznacznie powiększyła się w ciągu całego minionego stulecia.

Wydaje się, że ekspansja $S$. gigantea na terytorium Polski rozpoczęła się o kilkadziesiąt lat wcześniej, niż $S$. canadensis i przebiegała bardziej gwałtownie. W przypadku $S$. gigantea głównymi szlakami migracyjnymi były doliny rzek i potoków, a zwłaszeza dolina Wisły. Szlaki komunikacji drogowej i kolejowej odegrały ważną rolę w ekspansji obydwu gatunków.

Występowanie $S$. graminifolia związane jest w większości z podmokłymi i wilgotnymi siedliskami pochodzenia antropogenicznego (rowy, brzegi stawów. glinianek itp.). S. gigantea wyraźnie preferuje siedliska wilgotne, ale dzięki wyjątkowo szerokiej tolerancji stosunków wodnych, może także rosnąc w miejscach suchszych, tylko okresowo zasilanych przez opady. $S$. canadensis. natomiast, zdaje się być przywiązana do siedlisk umiarkowanie suchych.

Większość stanowisk $S$. canadensis w Polsce związana jest z siedliskami ściśle ruderalnymi. podczas gdy przeważająca część zbiorów $S$. gigantea pochodzi z siedlisk o charakterze na pół naturalnym.

W związu 7 wcią̇ postẹpuiąca dewastacią środowiska przyrodniczego. nieustannym naruszaniem terenów iuz zniszczonych. wzrastalącym zasiẹgiem komunikacii i transportu itp. zachodzi uzasadniona obawa, że w przyszłości nadal będą się utrzymywały w Polsce dogodne warunki do gwałtownego rozprzestrzeniania się $S$. canadensis i $S$. gigantea. Znaczna żywotność tych roślin oraz zdolność ich przenikania do na pół naturalnych zbiorowisk roślinnych stanowią biologiczne zagrożenie nie tylko dla roślinności rodzimej (np. lasów i zarośli łęgowych), ale również dla całych ekosystemów. 